Article

\title{
Hamlet the Heretic: The Prince's Albigensian Rhetoric
}

\author{
Benjamin Lockerd
}

Department of English, Grand Valley State University, Allendale, MI 49401, USA; lockerdb@gvsu.edu

Received: 19 November 2018; Accepted: 28 December 2018; Published: 29 December 2018

\begin{abstract}
Some of Hamlet's speeches reflect a dualistic view of the world and of humanity, echoing in particular some of the heretical beliefs of the Albigensians in southern France some centuries earlier. The Albigensians thought that the evil deity created the human body as a trap for the souls created by the good god, and Hamlet repeatedly expresses disgust with the body, a "quintessence of dust" (II.ii.304-305). Because they regarded the body as a soul trap, the Albigensians believed that marriage and procreation should be avoided. "Why wouldst thou be a breeder of sinners?" Hamlet demands of Ophelia, adding that "it were better my mother had not borne me" (III.i.121-24). He sounds most like a heretic when he goes on to say "we will have no more marriage" (III.i.147). Though Hamlet continues with dualistic talk nearly to the end, there is some turning toward orthodox Christianity.
\end{abstract}

Keywords: Hamlet; Albigensian heresy; Dualism; Catholicism

This essay will suggest that some of Hamlet's speeches reflect a dualistic view of the world and of humanity, echoing in particular some of the heretical beliefs of the Albigensians in southern France a couple of centuries earlier. I do not propose this interpretation as a definitive one that supersedes all the excellent scholarship of the past but as one more layer of meaning in this astonishingly complex and mysterious play, which continues to challenge us with "thoughts beyond the reaches of our souls" (I.iv.56). With some previous interpretations it may not be compatible, but with many it is.

The setting of the play is medieval and Catholic. The original telling of the Hamlet story by Saxo Grammaticus places the events in medieval (hence Catholic) Denmark. David Beauregard has demonstrated in overwhelmingly convincing detail that the play assumes a Catholic milieu (Beauregard 2008, pp. 86-108). He is right to conclude that "contrary to some recent critical claims, Hamlet does not appear to be a very Protestant play" (p. 87). Yet the anachronistic fact that Hamlet and Horatio have been studying at the university in Wittenberg (which was not founded until 1502) offers a tantalizing and unmistakable allusion to Luther and the Reformation, indicating that Protestant theology must somehow impinge on the play. Horatio's initial disbelief in ghosts also suggests the Protestant tendency to consider them illusions or else apparitions of spirits, either angelic or demonic, while Catholics typically thought that ghosts were souls in Purgatory (Shaheen 1999, p. 480). When first encountering the ghost, Hamlet, too, takes the Protestant perspective, supposing it must be either "a spirit of health or goblin damned" (Shakespeare 1969, I.iv.40). But the ghost identifies himself as the soul of his father, suffering in Purgatory, and, as Stephen Greenblatt points out, when Hamlet swears "by Saint Patrick" (I.v.136), he invokes the patron saint of Purgatory (Greenblatt 2001, p. 233). Thus these Wittenberg scholars have their Protestant assumptions rudely challenged, and the play begins with a theological confrontation.

To this clash of Protestant and Catholic views of the afterlife, I would add that some of Hamlet's talk later in the play reflects the dualistic doctrines of the Albigensians, who believed in a good god, creator of the spiritual world, and an equal evil god, creator of the physical world. In their view, the physical world was not only fallen but inherently evil. In his disgust with his uncle and mother, 
Hamlet begins to denounce the physical world itself, saying it is a prison (II.ii.236-45). In the same scene he declares that "this goodly frame the earth seems to me a sterile promontory; this most excellent canopy, the air ... appeareth nothing to me but a foul and pestilent congregation of vapors" (II.ii.295-99). The Albigensians also thought that the evil deity created the human body as a trap for the souls created by the good god, and Hamlet repeatedly expresses disgust with the body, a "quintessence of dust" (II.ii.304-305). Because they regarded the body as a soul trap, the Albigensians believed that marriage and procreation should be avoided. "Why wouldst thou be a breeder of sinners?" Hamlet demands of Ophelia, adding that "it were better my mother had not borne me" (III.i.121-24). He sounds most like a heretic when he goes on to say "we will have no more marriage" (III.i.147). Such extreme statements echo neither Catholic nor Protestant theology but the radical dualist belief that the physical world and the human body are fundamentally evil. Hamlet is motivated by his melancholic temperament, reacting to the shocking discovery of familial murder and what he regards as an adulterous and incestuous union-enough to give anyone doubts about the inherent goodness of creation. Yet it must be significant that the rhetoric he employs is strongly reminiscent of Albigensian doctrines. Driven by his personal despair, he adopts the despairing worldview of the most widespread and persistent heresy of the Middle Ages.

Before developing this argument further, I wish to reflect briefly on the larger discussion concerning Shakespeare and religion. A generation or two back, there was little talk of either his politics or his religion, the assumption being that he was agnostic in both of those debated realms of thought, or that his universal genius transcended such immediate issues. Christopher Baker surveys some of the critics who held that viewpoint, mentioning George Santayana, G. R. Elton, and Harold Bloom (Baker 2007, p. 57). More recently, however, there has been much serious discussion of our playwright's political and religious commitments. Given that he never speaks in his own voice in his plays, this could be a parlous endeavor, but those scholarly discussions have, in fact, opened up the plays in new and valuable ways. In his excellent survey of critical works on Shakespeare and religion for this special issue, John Cox notes that in recent years one trend has been toward seeing Shakespeare's depictions of religion, and references to it, as serving a mostly aesthetic and dramatic purpose rather than expressing religious belief of any kind. For instance, Cox quotes David Scott Kastan as saying that "Religion in the plays is a psychological and social reality that registers as form rather than a credal one that registers as belief" (Kastan 2014, p. 7; quoted by Cox 2018, p. 8). And he quotes Richard McCoy thus: "I now see faith in Shakespeare as more theatrical and poetic than spiritual" (McCoy 2013, p. ix; quoted by Cox 2018, p. 10). This looks like a return to the agnosticism of Shakespeare scholars of yore, but it is incoherent to suggest that religious elements in these plays can serve strictly aesthetic purposes: religious truth and religious beauty are too intertwined to allow such a line to be drawn. In fact, the connection between them is one of the debates of the Reformation era: Catholics holding that the aesthetic power of vestments, ritual, dialogue, and music draws us bodily into the mysteries; Protestants averring that all those are traditions of men, trappings that distract us from the inner spiritual reality. Traditional theology argues that the three Transcendentals-the Good, the True, and the Beautiful—are all aspects of God's Being and thus inseparable from each other. From this perspective, aesthetics and belief are not easily teased apart.

Critical appreciation for competing theological beliefs in Shakespeare's plays reminds us that Elizabethan drama had its roots in the medieval mystery plays and never stood much chance of becoming a purely secular art form. The medieval drama arose as part of the Easter liturgy (the famous quem quaeritis trope) and then developed into the cycle of mystery plays that retold Biblical history-and eventually into the more secularized drama of the Renaissance. Hamlet alludes to the mystery plays, which Shakespeare likely saw as a child, when he urges the players not to overact, for then "It out-herods Herod" (III.ii.13). Religious ceremony is a dramatic enactment, and Shakespeare shows himself intensely aware of the religious overtones of his dramas.

Take, for example, the repentance of Claudio in Much Ado. When he learns of his great error, he says to Leonato, "Impose me to what penance your invention / Can lay upon my $\sin$ " (V.i.260-61). 
His language is explicitly Catholic, referring to the sacrament of confession and the penance that is an essential element of it, though Leonato is not a priest. Protestants rejected this sacrament vociferously, along with the belief in Purgatory that was connected with it. Part of the penance Claudio is given is to place an epitaph on Hero's tomb, and Claudio does so in a separate scene, in which he reads his epitaph and has a song about her sung. He concludes the ceremony by promising, "Yearly will I do this rite" (V.iii.22). Though it does not follow prescribed forms, this is a "rite," a religious ritual, one that is intended to be repeated each year, and the ceremony is meant to represent a genuine repentance on the part of young Claudio, who has behaved so badly toward Hero that it is hard for the audience to forgive him. The religious language and ceremony here are familiar to the audience and integral to the drama; the ritual concentrates feelings of repentance and lays them before the Divine.

This small but important scene looks forward to the ceremony of repentance, forgiveness, and reconciliation at the end of The Winter's Tale, which, as Cox points out, is laden with religious language strongly evoking Christian belief: "To insist that such words have merely esthetic denotations is to ignore the connotations that give the plot much of its emotional vitality and depth" (Cox 2018, p. 10). In this special issue, Grace Tiffany ably and convincingly demonstrates the genuine religious beliefs at work in The Winter's Tale, although she exaggerates, it seems to me, Calvinist overtones in the play (Tiffany 2018, pp. 8-10). Tiffany's argument is that Leontes' penitential commitment to daily visits to the chapel where Hermione and Mamillius lie invokes Catholic practice (which it does) and is inefficacious: "Though he performs his pledge, these acts of ritual penitence do not mitigate his grief and guilt" (p. 8). True enough, but they prepare him spiritually for the forgiveness he receives at the end. Indeed, "Paulina is Pauline in her vigorous exhortations to virtuous behavior" (p. 9), but Catholics completely accept the teachings of Paul (though understanding them differently), and why is this "virtuous behavior" not to be seen as works? Again, Paulina's "explicit call for faith" (p. 9) is certainly Pauline, but Catholic theology strongly emphasizes the need for faith—while rejecting the Lutheran reduction to the Sola Fide dogma. A fascinating Catholic interpretation of Paulina is offered by Clare Asquith, who demonstrates convincing connections between Shakespeare's pivotal character and Lady Magdalen Browne, Viscountess Montague, an openly recusant aristocrat who died shortly before the play was written, and whose great nephew, Lord Strange, and grandson, the Earl of Southampton, were Shakespeare's patrons (Asquith 2005, pp. 36-42). In any case, this is where the debate should occur concerning the final scene of The Winter's Tale, between Catholic and Protestant readings, not over a question of whether there is any authentic religious thinking involved.

It is indeed difficult to say what the playwright's deepest beliefs were, given that he always speaks through dramatic characters, but there is ample evidence of real Christian belief throughout. If Shakespeare ever does speak in his own voice, it is in the Epilogue to The Tempest, spoken by Prospero, who is identified in many and unmistakable ways with the playwright himself. The Catholic significance of this final passage is demonstrated effectively by Beauregard, who shows in detail that "the twenty lines of the epilogue are interlaced with the technical language of sin and grace" (Beauregard 1997, p. 163). The epilogue is a retirement speech by one who is giving thought to his impending death, and it ends with a request for intercessory prayers: "As you from crimes would pardoned be / Let your indulgence set me free" (V.Epi.19-20). This echoes the Lord's Prayer, but it also uses affirmatively the most fraught word of the Reformation era. Whether his dramatic use of Catholic language, doctrine, and ritual clinches the argument that Shakespeare was a "church papist" will continue to be debated. Yet it is tempting to see this valedictory speech as William Shakespeare's version of the Catholic Spiritual Testament signed by his father, John Shakespeare, and hidden away in the rafters of his house (Beauregard 1997, p. 159). This one is hidden in plain sight but is sufficiently ambiguous to avoid prosecution. What matters to the general critical discussion is that Shakespeare's art is inseparable from the religious practices and tensions of his day.

Nowhere is this tension more prominent than in Hamlet, a play about a Catholic ghost in an increasingly Protestant world. One of the issues involved is the interpretation of the Albigensian movement. This sect arose in southern France in the 11th century. They were a neo-Manichean group, 
possibly influenced by preceding dualists such as the Bogomils in Bulgaria. A fairly even-handed article by Nicholas Weber in The Catholic Encyclopedia gives a concise account, emphasizing what is generally accepted by modern historians (Weber 1907). The name "Albigenses" (derived from the town of Albi) was used to denote this sect at the Council of Tours (1163), one of the many church councils that denounced them. They were also called Cathars, from katharos (pure), and this designation gives them something in common with the later Puritans, who also named themselves "pure." St. Bernard preached against their teachings, as did St. Dominic at a later time, but the Albigenses proved quite resistant to orthodox theology. Eventually, Pope Innocent III called for a crusade against them (in 1207), and much blood was shed over a period of many decades. The medieval Inquisition tried many of their leaders, turning them over to civil authorities for execution. Still, the Albigenses persisted for some time, having spread to parts of Spain, Italy, and Germany. It was not until sometime in the 14th century, nearly three centuries after its first appearance, that the sect finally disappeared.

This was no minor event in the history of Christianity, and it would have been well known to educated people in Shakespeare's time, two centuries later. In a recent and thoroughly researched book, Malcom Barber emphasizes the shock that this movement gave to the church:

Catharism was the greatest heretical challenge faced by the Catholic Church in the twelfth and thirteenth centuries. The attempt by the Cathars to find an answer to the fundamental religious and philosophical problems posed by the existence of evil, combined with their success in persuading large numbers of Christians in the West that they had solved these problems, shook the Catholic hierarchy to its very core, and provoked a series of reactions more extreme than any previously contemplated. (Barber 2013, p. 1)

Having exhausted the resources of preaching to the Cathars, and feeling that the very existence of the church was threatened, Pope Innnocent felt compelled to call for a crusade against them, though he knew it would be a bloodbath, as indeed it was. Memory of this brutal war did not fade by Shakespeare's time, and all educated people of that time must have been aware of the crusade and some of the theological issues involved. Catholic commentaries denounced the Albegensians as heretics, but some Protestant writers, especially those of the Puritan persuasion, saw them as noble reformers and martyrs, as we will see.

The Albigensians were indeed reformers, responding to the widespread corruption of the clergy at the time and calling for apostolic clerical poverty (as did the internal reform movements of the Dominicans and Franciscans). In a deeply researched book on the subject, H. J. Warner repeatedly calls attention to the legitimate aims of the Cathars. He argues that their dualism was emphasized less than their call to morality of life. When candidates for admission to the sect were catechized, he tells us, they were not asked to affirm the dualist doctrine: "Thus discipline of life was presented to them not as a struggle with an evil God, but as a following of Apostolic Christianity and a practical protest against a corrupt hierarchy" (Warner 1922, p. 88). Since it was an earlier reform movement, it tended to be viewed sympathetically by Protestants of Shakespeare's time, in spite of its heterodox teachings.

What were those teachings? The Albigenses believed in two equal deities: a good principle, who created the spiritual world and human souls; and an evil principle, who created the physical world and the human body as a trap for souls. They rejected the Old Testament as a creation of the evil god. They denied the full doctrine of the Incarnation, asserting that Jesus Christ only appeared to be born of Mary, only appeared to be embodied and came to free souls from their bodies. Naturally, they rejected the doctrine of the resurrection of the body. The Trinitarian doctrine was cast aside, for the Albigenses regarded the son and the spirit as created beings, not equal to the good god. They also renounced the sacraments and instead offered their adherents just one ceremony, the "Consolation," in which a laying on of hands signified a purification from all sin. As Barber explains,

Catharism represented total opposition to the Catholic Church, which was viewed by the Cathars as a false and fraudulent organisation which had prostituted itself for power and ill-gotten wealth. The sacraments through which the Catholic Church claimed to open the 
way to salvation were quite valueless, since they were founded upon the claim that Christ really had lived on earth, had been crucified, and then resurrected, events clearly impossible, since God could not have taken on material form in the first place. (Barber 2013, p. 2)

Thus they returned to controversies of the early centuries of Christianity concerning the nature of Jesus Christ, siding with those who denied the central doctrine of the Incarnation. It followed that sacraments, which all employ physical elements and recall Christ's physical life on earth, would also be declared invalid.

The whole aim of Albigensian practice was to liberate the soul from the body. Ordinary members were called "credentes" (believers); the more advanced priestly adherents were the "perfecti" (perfect), and they practiced a more severe asceticism. The believers would typically wait until they thought themselves near death before receiving the Consolation, after which they often sought to die while in that state of grace. If death did not come quickly they would typically starve themselves, a process of passive suicide they called the endura (Barber 2013, pp. 114-15).

Given that they believed the body to be a prison of the soul, the Cathars considered marriage and procreation to be evil. Members (especially the Perfect) were encouraged to remain celibate, or, even if not celibate to disdain marriage and avoid procreation. Here is Barber's description of these beliefs, quoting contemporary sources:

Good matrimony was when 'our soul was joined to God through good will, and that was the sacrament of matrimony.' In contrast, 'carnal matrimony' was not matrimony at all, and carnal intercourse between husband and wife was 'always a sin', even more than if a man had intercourse with a woman who was a stranger, as carnal acts between those who were married were more frequent and therefore engendered greater shame. (Barber 2013, p. 113)

In the Cathar account of the Fall, the evil god, Satan, is the creator of the physical world and the bodies of Adam and Eve. He tricks souls into inhabiting those bodies. Satan himself impregnates Eve, and all her offspring are therefore known as "sons of the devil" (Barber 2013, pp. 96-97). Further procreation is thus to be avoided.

With this background in mind, let us turn to the play. In Hamlet's first soliloquy he bemoans "this too too sullied flesh" (I.ii.129), expressing an extreme disgust at his corporeal existence-both too solid and too besmirched. He goes on to indict the entire world: "O God, God, / How weary, stale, flat, and unprofitable / Seem to me all the uses of this world! / Fie on it, ah fie, 'tis an unweeded garden / That grows to seed" (I.ii.132-36). Naseeb Shaheen points out that Shakespeare is here using a commonplace metaphor, "since a garden, whether properly cared for or neglected, was to Elizabethans an image of the world" (Shaheen 1999, p. 474). The garden symbol naturally calls to mind the Garden of Eden, seen as corrupted with weeds and untended after the Fall. Perhaps its growing to seed suggests the unprofitable generation of people as well as plants. This goes beyond a reference to the Fall in the orthodox understanding, in which both human kind and the world itself are understood to be created good but corrupted by the Original Sin: the world seems to Hamlet inherently and irremediably corrupt.

Hamlet acknowledges that God has "fixed / His canon 'gainst self-slaughter" (131-32) but wishes it were not so. He here reveals a melancholic temperament responding to his father's sudden death and his mother's shockingly quick remarriage to his uncle. However, his words reflect the Cathars' contentions that the physical world and the body are not only fallen but innately evil, as well as their desire to free their souls from their bodies by suicide. He is held back by orthodox beliefs, but his longing for death is couched in terms that echo dualistic disgust with the world and the body.

After his meeting with his father's ghost, Hamlet's melancholy is naturally intensified, and from the first it seems that his madness is not entirely feigned, or that it has more of an edge to it than would be necessary to throw Claudius off the scent. Speaking with Polonius, and apropos of nothing, he launches into talk of reproduction: "For if the sun breed maggots in a dead dog, being a good kissing 
carrion-Have you a daughter?" (II.ii.181-82). The revolting image of the spontaneous generation of maggots in rotting flesh sets the tone for all his remarks on the subject, and he quickly identifies that sort of generation with human procreation, adjuring Polonius, "Let her not walk i' th' sun. Conception is a blessing, but as your daughter may conceive, friend, look to ' $t$ " (184-86). This addresses Polonius's own fears about Ophelia walking too much in the sunny affection of the prince, but it also generalizes a profound doubt about the value of procreation. Conception is thought to be a blessing, but Hamlet will never again acknowledge that; instead, he will consistently see it as something foul, an act that perpetuates the evil physical world, begetting worms out of the rottenness of the flesh. The allusion here to the old idea of spontaneous generation further reduces human sexual love to something that involves no soul or mind or emotion at all, something completely physical, not spiritual. Polonius is aware that there is some method in this madness, though he does not appreciate the irony of his own statement: "How pregnant sometimes his replies are!" (206-207).

Rosencrantz and Guildenstern now enter the scene, and Hamlet greets them by asking, "What have you, my good friends, deserved at the hands of Fortune that she sends you to prison hither?"

\section{Guildenstern: Prison, my lord?}

Hamlet: Denmark is a prison.

Rosencrantz: Then is the world one.

Hamlet: A goodly one; in which there are many confines, wards, and dungeons, Denmark being one $\mathrm{o}^{\prime}$ th' worst. (II.ii.237-45)

It is not only Denmark that seems a prison house to him but the whole weary and unprofitable world. As the conversation continues, Hamlet tells them that he has "lost all my mirth," to the point where "this goodly frame the earth seems to me a sterile promontory; this most excellent canopy, the air, look you, this brave o'erhanging firmament, this majestical roof fretted with golden fire-why it appeareth nothing to me but a foul and pestilent congregation of vapors" (293-99). Just as he knows that conception is a blessing, he knows the world is beautiful, and he describes it beautifully-but only to highlight his own sense that it is loathsome. He has ceased to believe, it would seem, that on the last day there will appear "New heaven and new earth" (Rev. 21:1).

Man is similarly beautiful: "What a piece of work is a man, how noble in reason, how infinite in faculties; in form and moving how express and admirable, in action how like an angel, in apprehension how like a god: the beauty of the world, the paragon of animals! And yet to me what is this quintessence of dust?" (300-5). All Christians believe that human beings were created from earth, but they also take seriously the words of Genesis telling them that they were created in the image and likeness of God. It was common in Shakespeare's age to see the human body, however fallen, as reflecting the immortal soul. To see dust as the very essence, the fundamental nature of the human body is indeed heterodox. As John Curran puts it, "If our quintessence is of dust, this implies the elimination of all other ways truthfully to see ourselves" (Curran 2006, p. 12). Curran sees in this statement a Protestant view of humanity; my suggestion is that the Protestant view tends toward something even more disgusted by the flesh, the Cathar vision of the body as purely evil. Shaheen compares this passage to Psalm 8:

What is man that thou art mindful of him: and the sonne of man that thou visitest him? Thou madest him lower than the angels: to crowne him with glory and worship. Thou makest him to haue dominion of the works of thy hands: and thou hast put all things in subiection vnder his feete. (Ps. 8.4-6)

Hamlet's speech does echo this passage, especially in seeing man as created just a little lower than the angels on the chain of being. But he reverses the line of thought: the Psalm begins with an 
acknowledgment of mankind's unworthiness and then marvels that nevertheless the Creator made us almost angelic and gave us dominion over all other creatures; Hamlet begins with a beautiful description of human nobility but ends in disgust at the physical composition of our bodies out of dust. This reverses the words of human creation in Genesis itself, where God begins with clay but breathes into it an immortal soul. According to the Cathars, the good god made only souls, which were then tricked by the evil one into entering bodies made of clay and thus trapped. Hamlet's speech resonates with such a dualistic belief.

It is in the next scene that Hamlet speaks most like an Albigensian. In his most famous soliloquy, he continues to contemplate suicide, though his fear of the dreams that might come "When we have shuffled off this mortal coil" (III.i.67) is orthodox. The "coil" refers to the turmoil and disturbance of our mortal life, which the melancholic and the Cathar view as being the whole of it. In the following conversation with Ophelia before the play, Hamlet condemns procreation: "Get thee to a nunnery. Why wouldst thou be a breeder of sinners?" (III.i.121-22). His play on the slang meaning of a nunnery as a brothel makes the situation even more hopeless, associating even celibacy with carnality (as did many Puritan preachers as well). Curiously, the Albigensians were sometimes reported by their Catholic critics (whether accurately or not is hard to tell) as rejecting marriage but practicing sodomy as a way of satisfying their carnal desires while avoiding producing children. The word "breeder" emphasizes the animality of sexual love, and this passage echoes the earlier reference to breeding maggots. It is, of course, perfectly traditional to say that when one begets children one brings into the world human beings who will certainly be sinners, but the implication that children are completely defined by their sinfulness is shockingly heretical in its denial of redemption and grace. Hamlet refers to Original Sin moments earlier, proclaiming that "virtue cannot so inoculate our old stock but we shall relish of it" (117-18). To deny the efficacy of virtue might be simply a Protestant rejection of works theology, but the tone here is one of complete hopelessness: there is nothing that can overcome the evil of a world created by an evil god. Only the death of the body can release the soul.

Hamlet continues his diatribe against procreation: "I am myself indifferent honest, but yet I could accuse me of such things that it were better my mother had not borne me ... " (122-23). Even though he is fairly honest, it would be better had he never been born; it would be better if no one were born. Here he comes close to Lear's demand that the storm should "Crack Nature's moulds, all germains spill at once, / That makes ingrateful man" (III.ii.8-9), but where Lear is expressing misanthropy, Hamlet couches his rejection of procreation in Christian terms. What he says runs contrary to the divine injunction in Genesis to "be fruitful and multiply" (Gen. 1.28). To avoid breeding more sinners, Hamlet decrees, people should practice celibacy (or the anti-procreative sexuality of the brothel), and marriage must be rejected: "I say we will have no more marriage. Those that are married already-all but one-shall live. The rest shall keep as they are. To a nunnery, go" (147-49). This renunciation of marriage is neither Protestant nor Catholic. The Protestants insisted that even ministers should be free to marry, and for Catholics marriage was one of the seven sacraments. For both, one of the essential purposes of marriage was begetting and raising children. In denouncing both procreation and marriage, Hamlet sounds very much like an Albigensian.

In the last two acts, Hamlet continues to express dualistic beliefs. Asked what he has done with Polonius's dead body, he replies that he has "Compounded it with dust, whereto 'tis kin" (IV.ii.6). Again, to say our bodies are made from dust and return to dust is ordinary Christian teaching, but to say that we are kin to dust smacks of a radical rejection of the body. Similarly, to declare that "We fat all creatures else to fat us, and we fat ourselves for maggots" (IV.iii.21-23) is to focus morbidly on the decay of the body, forgetting the belief, expressed in the ancient Apostles' Creed, in the "resurrection of the body." In the wonderful and powerful graveyard scene, Hamlet continues his meditation on bodily decay while looking at skulls being tossed from the ground. With mordant wit, he imagines "the noble dust of Alexander ... stopping a bunghole" (V.i.191-92) and

Imperious Caesar, dead and turned to clay,

Might stop a hole to keep the wind away. 
Oh that that earth that kept the world in awe

Should patch a hole t'expel the winter's flaw! (V.i.200-203)

Saints down through the ages have meditated on the body's decay, and some, such as St. Jerome, kept a skull handy as a memento mori. David Beauregard (following Louis Martz) notes a very similar passage in Luis de Granada's Of Prayer and Meditation (Beauregard 2008, p. 87). Yet the bitter tone of these lines seems to dwell on the death of the body in a way that denies its eventual resurrection on the last day. The Doctor of Divinity who presides over the "maimed rites" for Ophelia explains,

Her obsequies have been as far enlarged

As we have warranty. Her death was doubtful,

And, but that great command o'ersways the order,

She should in ground unsanctified have lodged

Till the last trumpet. (V.i.213-16)

Shaheen cites 1 Cor. 15.52: "At the last trumpet: for the trumpet shall blowe, and the dead shall be raised vp" (Shaheen 1999, p. 492). Here is a reminder of orthodox dogma, the belief that suicide is a mortal sin precluding burial in consecrated ground, and the belief that at the last trumpet all bodies will be raised from the ground to be knit together again and reunited with their souls in heaven or hell. The priest's words stand in contrast to those of Hamlet.

Though Hamlet continues with dualistic talk nearly to the end, there is some turning toward orthodox Christianity. After his near-death experiences at sea, he is "set naked" back on Danish soil (IV.vii.43), a type of Jonah brought back renewed and chastened to prophesy to the sinful world. He proclaims himself boldly at the graveyard: "This is I, / Hamlet the Dane" (V.i.244-45), asserting not only his identity but his kingship. And he proclaims unambiguously his love for Ophelia, implicitly acknowledging the goodness of sexual love and marriage. Peter Milward also sees this return to Christian belief, suggesting that "something in Hamlet's conscience is awakened ... by the burial of Ophelia, which is in a sense arranged for him by divine providence ... he comes to reveal a Christlike spirit of forgiveness in the end" (Milward 1987, p. 5). At the beginning of the final scene, the Prince remembers that God cares for worms like him, crawling between heaven and earth: "There is special providence in the fall of a sparrow" (V.ii.208-209). He here recalls the words of Jesus: "Are not two sparrows sold for a farthing, and one of them shal not fall on the ground without your Father?" (Matthew 10:29, quoted by Shaheen 1999, p. 493). Even the lowliest creatures of the physical world were created good and are held in the providential care of the Creator; so too Hamlet. I cannot agree with Curran when he frames this reference to Providence as a capitulation to the Calvinist denial of free will and a deterministic sense that "nothing can be otherwise than it is" (Curran 2006, p. 205). Hamlet expresses, it seems to me, a peaceful resignation, not a despairing one. Significantly, Hamlet asks pardon of Laertes before they fence, and as they are dying Laertes begs, "Exchange forgiveness with me, noble Hamlet. / Mine and my father's death come not upon thee, / Nor thine on me!"- to which Hamlet responds charitably, "Heaven make thee free of it!" (V.ii.318-21). It is a scene of Christian forgiveness worthy of the romances and predicated on the orthodox belief that our sins have been atoned for and may be forgiven. These are strong hints that Hamlet returns to his senses and embraces orthodox belief at the end.

Let us not claim to have plucked out the heart of Hamlet's mystery (III.ii.351), yet we may hope to shed some light upon it. Religious questions are particularly insistent and fascinating in Hamlet and have stimulated excellent critical evaluations. Some have concluded that within the play Shakespeare does not take sides in the Protestant-Catholic debate. For instance, Peter Iver Kaufman compares Hamlet's famously troubled self-reflection to a movement within Protestant circles to encourage "a regimen of self-lacerating introspection," which they often called "Christian clearing" (Kaufman 2011, p. 428). However, Kaufman also notes that a very similar emphasis on brutal self-examination was promoted in Catholic circles, especially in the spiritual exercises of the Jesuits (pp. 434-35). Kaufman offers a refreshingly irenic acknowledgment of the common ground that Catholics and Protestants shared, 
though they often refused to admit it. Maurice Hunt has reached a similar conclusion: "my argument discovers the surprising extent of Shakespeare's amalgamation of Protestant and Catholic motifs and ideas in single images, concepts, and characterizations" (Hunt 2004, p. ix). Still, Protestant and Catholic beliefs are in many places in the play kept distinct from each other and seen as opposed.

As a witness to the theological intensity of Hamlet, a fine collection of essays on Shakespeare and Christian culture edited by Dennis Taylor and David Beauregard contains three pieces on this one play, each offering a distinct perspective. John Freeman finds echoes of recusant writers: “Called back from Wittenberg, the seat of Protestant learning, Hamlet struggles with the demands of a Catholic past pressed upon him by his phantasmal father" (Freeman 2003, p. 250). Freeman convincingly finds a Catholic Hamlet, but a conflicted and even reluctant one. Jennifer Rust also points to Hamlet's connection with Wittenberg and follows earlier critics in noting the "conflation of the historical Diet of Worms with the decaying body of Polonius" (Rust 2003, p. 260). The Diet of Worms was an assembly called by the Holy Roman Emperor in 1521 to question Martin Luther. There he famously said he could not recant his teachings but must follow the Scriptures and his own conscience. It was the point of no return. Luther was given safe conduct when he departed, but the Edict of Worms declared him a heretic and ordered his capture. The irresistible play on words employed by Shakespeare (a "diet," or assembly of leaders, in the city of Worms / worms dieting on Polonius) strongly evokes this historical moment. Rust also points out that Tyndale's translation of the Bible was published in Worms in 1527, connecting that city yet more closely to the Reformation in England. The main point of Rust's essay is that a particular type of melancholy, "spiritual melancholy," was recognized at that time and spoken of in Burton's Anatomy of Melancholy, as well as other sources. Her contention is that Hamlet suffers from that sort of melancholy, which comes about from an inauthentic religious impulse. "Though Wittenberg may have been particularly redolent of spiritual melancholy," she writes, "the condition itself was clearly a source of concern in Calvinist England as well" (Rust 2003, p. 266). This interpretation also seems reasonable, and it leads into the third essay, by R. Chris Hassel, on "Hamlet's Puritan Style," in which the author "explores the ways in which Hamlet's outspoken, even hyperbolic, righteousness towards himself and others echoes the unique diction, syntax, and imagery of the represented Puritan, if not always the real one" (Hassel 2003, p. 287). This analysis is consistent in some ways with Hassel's earlier essay on "Hamlet's 'Too, Too Solid Flesh,"' in which he argues that "Hamlet's compulsion to do and to know perfectly is part of a larger paradigm of egotism which Luther variously calls the 'idols,' 'snares,' or 'traps' of the flesh" (Hassel 1994, p. 616). So we have (in just one book) Hamlet as a recusant (albeit a reluctant one), a sufferer from spiritual melancholy, and a Puritan-with all three essays offering compelling support. It seems we are no more likely than his erstwhile friends to pluck out Hamlet's mystery, yet there are important revelations in these efforts.

Hassel's chapter is the only place where I have come across reference to the Albigensians in relation to the play. He cites Patrick Collinson's book on English Puritanism: "Collinson points to the 'insinuation of the ancient heresy of perfectionism,' Novationism, Catharism, Albigensianism, what you will, as one of the benchmarks of Puritanism" (Hassel 2003, p. 301). The tendency of English Calvinists (at least the stereotypical ones) toward a self-righteous perfectionism can lead in the direction of a hyper-spiritualism that rejects the body as evil and thus in the direction of Catharism. Collinson indicates that the connection between Puritan and Cathar (and, again, the two terms meant "pure") was made by critics of the Puritans. He gives as an instance "that master of invective, the ex-Carmelite monk John Bale. Writing in the reign of Mary of some of his fellow protestant exiles, he attacked them as 'our Catharites or brethren of the purity'" (Collinson 1987, p. 8). The connection between Cathar and Puritan was primarily made, then, by opponents of these zealous English Calvinists, yet Puritan writers did not reject the association.

Indeed, the Puritans often recognized a kinship with those medieval heretics, regarding them as early reformers. For instance, John Foxe, in his very popular book of Protestant martyrs, Acts and Monuments, includes both Waldensians and Albigensians among the martyrs (Foxe 1583). A little after the time of the play, J. P. Perrin wrote Luthers fore-runners: Or, a cloud of witnesses deposing for 
the Protestant faith, and his title page states that the book is divided into three parts: "The second containes the historie of the Waldenses called Albigenses" (Perrin 1624). Perrin thus includes both sects (identified as one) among the fore-runners of Luther. Perhaps Shakespeare is assuming that the dualist heresies mouthed by Hamlet in his agony align with the ideas of those fervent Protestants who had come to be known as Puritans.

John Foxe was certainly the most famous of the English Puritan writers in Shakespeare's time, and he embraces the connection with the Albigensians. Leonard Tinterud summarizes Foxe's Preface thus:

This world had always had two churches, God's true church and the devil's chapel nearby. The true church had seldom been visible, and had usually been small and under persecution, discernible only to those who were its members. The false church had usually been visible, powerful, pompous, wealthy, cruel and persecuting — a clerical church ... The clerical false church had charged the true persecuted church with heresy. (Tinterud 1971, p. 44)

Foxe assumed that any group persecuted by the Church of Rome and called heretical was actually part of the true Church. Here is how he himself puts it in the section where he discusses the Albigensians:

What these Albigenses were, it cannot be well gathered by the old popish histories: for if there were any who did hold, teach, ore maintain against the pope, or his papal pride, or withstand and gainsay his beggarly traditions, rites, and religions, \&c. the historians of that time, in writing of them, do, for the most part, so deprave and misreport them (suppressing the truth of their articles) that they make them and paint them forth to be worse than Turks and infidels ... otherwise it is to be thought (and so I find in some records) that the opinions of the said Albigenses were sound enough ... (Foxe 1870, p. 356)

Clearly, the Puritans did not endorse the dualistic ideas that the Albigensians had been accused of holding. As a recent historian, Abraham Friesen, puts it, " ... all of those who, in one fashion or another, saw themselves as heirs to the medieval heretics were not really interested in what the latter stood for-with the possible exception of Foxe's interests in Wycliffe. Beginning with Luther and the martyrologists, they were primarily interested in legitimating themselves against the attacks of the Catholics, and they sought to use the medieval heretics to accomplish this" (Friesen 1998, p. 189). Nevertheless, to a writer with Catholic leanings, such as Shakespeare, it would have been tempting to see the Puritans as veering toward the old heresy by their perfectionism and their rejection of the physicality of the Catholic Church's sacraments, ceremonials, festivals, and icons. His depictions of Malvolio in Twelfth Night and Angelo in Measure for Measure signal an anti-Puritan attitude. Hamlet's preaching against the wickedness of the world and the body registers not only Puritanical rhetoric but Cathar. This is not to say, of course, that Shakespeare's tragic hero consciously adopts the teachings of the medieval heretics. But in his melancholic railing against the sins of his mother and uncle and against the deviousness of nearly everyone around him, Hamlet falls into rhetorical excesses that echo those old dualistic doctrines. His terrible confusion of heart becomes a theological confusion which rejects traditional truths of the Christian Faith.

Dualism is perennially attractive because it satisfies an intuitive sense that the world is in fact very bad, full of both natural evils and moral evil. St. Augustine was famously drawn to the Manichean version, and after his conversion to orthodox Christianity he worked hard to confute it and to develop an alternative theology of good and evil. In his Theodicy (worked out in his Confessions and elsewhere), he argues that evil is not a separate being but rather is non-being, an absence of good. In this view, even Satan was created good and chose evil, which meant choosing to deny the good in himself and diminish his own being. Thus Dante describes him as a pathetic beast frozen in the ice and barely able to move, unable to speak (Inferno, canto xxxiv). In Paradise Lost, Milton initially presents Satan as newly-fallen and still attractive and powerful, but he fades as he continues to choose malice until he actually makes himself into a serpent (Lewis 1942, p. 97). His offspring, Death, is a shapeless 
shadow without any real substance (Paradise Lost, Book II). The struggle between Good and Evil in this orthodox theological perspective is ultimately no struggle at all, for evil is self-defeating. Still, it often does not seem that way, especially to those seeking spiritual perfection while confronting profound evil in this vale of tears. Such a one is Hamlet.

Funding: This research received no external funding.

Conflicts of Interest: The author declares no conflicts of interest.

\section{References}

Asquith, Clare. 2005. Shadowplay: The Hidden Beliefs and Coded Politics of William Shakespeare. New York: Public Affairs. Baker, Christopher. 2007. Religion in the Age of Shakespeare. Westport: Greenwood Press.

Barber, Malcolm. 2013. The Cathars: Dualist Heretics in Languedoc in the High Middle Ages, 2nd ed. Harlow: Pearson. Beauregard, David N. 1997. New Light on Shakespeare's Catholicism: Prospero's Epilogue in The Tempest. Renascence 49: 159-74. [CrossRef]

Beauregard, David N. 2008. Catholic Theology in Shakespeare's Plays. Newark: University of Delaware Press.

Collinson, Patrick. 1987. English Puritanism, rev. ed. London: The Historical Society.

Cox, John D. 2018. Shakespeare and Religion. Religions 9: 343. [CrossRef]

Curran, John. 2006. "Hamlet," Protestantism, and the Mourning of Contingency. Aldershot: Ashgate.

Foxe, John. 1583. Acts and Monuments: The New and Complete Book of Martyrs. 2 vols. London: John Day.

Foxe, John. 1870. The Acts and Monuments of John Foxe, 3rd ed. London: George Seeley, vol. 2.

Freeman, John. 2003. This Side of Purgatory: Ghostly Fathers and the Recusant Legacy in Hamlet. In Shakespeare and the Culture of Christianity in Early Modern England. Edited by Dennis Taylor and David Beauregard. New York: Fordham University Press, pp. 222-59.

Friesen, Abraham. 1998. Medieval Heretics or Forerunners of the Reformation: The Protestant Rewriting of the History of Medieval Heresy. In The Devil, Heresy and Witchcraft in the Middle Ages. Edited by Alberto Ferreiro. Leiden: Brill, pp. 165-89.

Greenblatt, Stephen. 2001. Hamlet in Purgatory. Princeton: Princeton University Press.

Hassel, R. Chris, Jr. 1994. Hamlet's “Too, Too Solid Flesh”. The Sixteenth Century Journal 25: 609-22. [CrossRef]

Hassel, R. Chris, Jr. 2003. The Accent and Gait of Christians: Hamlet's Puritan Style. In Shakespeare and the Culture of Christianity in Early Modern England. Edited by Dennis Taylor and David Beauregard. New York: Fordham University Press, pp. 287-310.

Hunt, Maurice. 2004. Shakespeare's Religious Allusiveness: Its Play and Tolerance. Aldershot: Ashgate.

Kastan, David Scott. 2014. A Will to Believe: Shakespeare and Religion. Oxford: Oxford University Press.

Kaufman, Peter Iver. 2011. Hamlet's Religions. Religions 2: 427-48. [CrossRef]

Lewis, C. S. 1942. A Preface to "Paradise Lost". Oxford: Oxford University Press.

McCoy, Richard. 2013. Faith in Shakespeare. Oxford: Oxford University Press.

Milward, Peter. 1987. Biblical Influences on Shakespeare's Great Tragedies. Bloomington: Indiana University Press.

Perrin, J. P. 1624. Luthers Fore-Runners: Or, a Cloud of Witnesses Deposing for the Protestant Faith. London: Nathanael Newbery.

Rust, Jennifer. 2003. Wittenberg and Melancholic Allegory: The Reformation and Its Discontents in Hamlet. In Shakespeare and the Culture of Christianity in Early Modern England. Edited by Dennis Taylor and David Beauregard. New York: Fordham University Press, pp. 260-86.

Shaheen, Naseeb. 1999. Biblical References in Shakespeare's Plays. Newark: University of Delaware Press.

Shakespeare, William. 1969. The Complete Works. Edited by Alfred Harbage. New York: Penguin.

Tiffany, Grace. 2018. Paganism and Reform in Shakespeare's Plays. Religions 9: 214. [CrossRef]

Tinterud, Leonard J., ed. 1971. Elizabethan Puritanism. New York: Oxford University Press.

Warner, H. J. 1922. The Albigensian Heresy. New York: Russell and Russell, vol. 1.

Weber, Nicholas. 1907. Albigenses. In The Catholic Encyclopedia. New York: Robert Appleton, vol. 1.

( 2018 by the author. Licensee MDPI, Basel, Switzerland. This article is an open access article distributed under the terms and conditions of the Creative Commons Attribution (CC BY) license (http://creativecommons.org/licenses/by/4.0/). 